\title{
STUDI GLOBAL ATAS MITIGASI DAMPAK PANDEMI COVID-19 MELALUI KEBIJAKAN PAJAK
}

\author{
Zefanya Lisnarossa Damahendra ${ }^{1}$, \\ Ari Budi Kristanto ${ }^{2 *}$ \\ ${ }^{1}$ Fakultas Ekonomika dan Bisnis, Universitas Kristen Satya Wacana \\ Email: 232017102@student.uksw.edu \\ ${ }^{2}$ Fakultas Ekonomika dan Bisnis, Universitas Kristen Satya Wacana \\ *Corresponding Author: Email: ari.kristanto@uksw.edu
}

\begin{abstract}
Abstrak
Penelitian ini bertujuan untuk memetakan kebijakan perpajakan negara-negara secara global terkait upaya mitigasi dampak pandemi COVID-19. Populasi dalam penelitian ini adalah negara-negara di seluruh dunia dengan menggunakan teknik purposive sampling dihasilkan sampel sebanyak 121 negara. Penelitian ini mendeskripsikan secara kualitatif tentang kebijakan pajak secara global berdasarkan data sekunder berupa tax policy measure yang diterbitkan oleh OECD. Hasil penelitian ini menunjukan bahwa kebijakan pajak yang diterapkan pada masa pandemi antara lain kebijakan penangguhan pembayaran pajak, penanggguhan pelaporan pajak, mempercepat pengembalian pajak, keringanan pajak, pembayaran pajak yang lebih fleksibel, dan meningkatkan kompensasi kerugian. Penangguhan pembayaran dan pelaporan pajak dilakukan dengan memperpanjang batas pelaporan dan pembayaran diluar tanggal normal. Pengembalian pajak diberikan kepada wajib pajak atas dana pajak yang telah dibayarkan berdasarkan ketentuan yang diterapkan oleh setiap negara dan keringanan pajak diberikan dengan tujuan untuk mengurangi beban pembayaran pajak. Pembayaran pajak yang lebih fleksibel dilakukan untuk mempermudah sistem pembayaran pajak selama pandemi dan kompensasi kerugian ditingkatkan untuk membantu perusahaan yang menghadapi risiko likuiditas dan solvabilitas. Kebijakan pajak yang diterapkan secara umum difokuskan pada jenis pajak CIT, PIT, VAT, pajak konsumsi, dan pajak properti. Penelitian ini diharapkan bermanfaat dalam menambah literatur bagi masyarakat agar masyarakat mengetahui upaya pemerintah terkait kebijakan pajak selama pandemi COVID-19.
\end{abstract}

Keywords: perpajakan, kebijakan pajak, COVID-19

\section{PENDAHULUAN}

Pandemi COVID-19 berdampak pada berbagai aspek kehidupan masyarakat, termasuk berisiko pada penurunan penerimaan pajak negara (OECD, 2020e). Menurut (OECD, 2020c), kebijakan physical distancing selama pandemi COVID-19 mengakibatkan sebagian industri memutuskan untuk mengurangi maupun menghentikan kegiatan produksinya. Penurunan tingkat produksi mengakibatkan laba yang diterima juga berkurang yang berefek pada penerimaan pajak pemerintah. Data penerimaan pajak Indonesia tahun 2020 masing-masing sebesar Rp 80,22 triliun pada bulan Januari, Rp 72,7 triliun pada bulan Februari, Rp 88,69 triliun pada bulan Maret, dan Rp 135,06 triliun pada bulan April (Kementerian Keuangan RI, 2020). Kementerian Keuangan RI (2020) menyatakan meskipun terjadi pertumbuhan positif juga terjadi perlambatan yang signifikan bila dibandingkan pada penerimaan pajak tahun 2019 pada periode yang sama. Penurunan penerimaan pajak akibat pandemi juga terjadi di Korea Selatan pada kuartal pertama 2020 yang turun sebesar 8,5 triliun (L. E. Joo, 2020).

Penurunan kinerja perekonomian akibat kondisi global saat ini menyebabkan adanya dualisme kebijakan pajak yang menjadi dilema bagi pemerintah. Pajak selain berfungsi sebagai budgeter yaitu sumber penerimaan negara, pajak juga berfungsi sebagai regulerend yaitu alat yang digunakan oleh pemerintah untuk mengatur keseimbangan perekonomian suatu negara melalui kebijakannya (Rohendi, 2014). Di tengah kondisi COVID-19, pemberian insentif pajak menjadi salah salah satu kebiijakan pajak yang banyak diterapkan oleh setiap negara. Pemerintah mengharapkan beban dari kebijakan pemungutan pajak dapat ditekan dengan adanya insentif pajak tersebut dan wajib pajak terdampak dapat menggunakan pendapatannya saat itu untuk mempertahankan operasional bisnis sehingga terhindar dari risiko likuiditas. Namun disisi lain kebijakan insentif pajak tersebut dapat mengurangi pendapatan negara dan juga kebijakan tersebut tidak dapat menjamin meningkatnya voluntary compliance, justru sebaliknya dapat dimanfaatkan untuk penghindaran pajak (Utama, 2020). Kementerian Keuangan 
Republik Indonesia menerapkan kebijakan penangguhan pembayaran pajak bagi wajib pajak badan maupun wajib pajak orang pribadi yang terdampak pandemi COVID-19 (Peraturan Menteri Keuangan Tentang Insentif Pajak Untuk Wajib Pajak Terdampak Pandemi Coronavirus Disease 2019, 2020). Pemerintah berupaya menerapkan kebijakan tersebut untuk menstabilkan perekonomian masyarakat namun disisi lain kebijakan tersebut berisiko pada penurunan penerimaan pajak (Harahap et al., 2018).

Dampak pandemi COVID-19 memiliki efek yang serupa dengan kondisi global ketika terjadi krisis ekonomi yang juga mempengaruhi penerimaan pajak negara. Pham (2020) menyatakan krisis ekonomi global yang terjadi di Vietnam tahun 2008 membuat pemerintah setempat menerapkan kebijakan pajak dengan memotong PPh badan (corporate income tax) dan menunda pembayaran $\mathrm{PPh}$ badan selama sembilan bulan. Penelitian lain dari Amerika juga menjelaskan bahwa pemerintah setempat menerapkan kebijakan berupa pemotongan pajak dividen ketika terjadi krisis ekonomi (Yagan, 2015). Penelitian sebelumnya membahas terkait kebijakan pajak yang diterapkan oleh pemerintah ketika terjadi krisis ekonomi, namun lingkup penelitian terbatas hanya pada kebijakan satu negara yaitu Vietnam dan Amerika Serikat. Dengan demikian, penelitian saat ini akan dikembangkan pada respon negara-negara dalam data statistik OECD melalui kebijakan pajak yang diterapkan ketika pandemi COVID-19.

Timbulnya dualisme kebijakan pajak dimana pajak seharusnya berfungsi sebagai budgeter dan regulerend menjadi tantangan bagi pemerintah dalam upaya menerapkan kebijakan pajak. Hal ini disebabkan karena pemerintah harus menerapkan kebijakan pajak yang dapat menjaga stabilitas perekonomian namun juga tidak memberatkan bagi wajib pajak. Sebelum pandemi COVID-19, peristiwa serupa juga pernah terjadi seperti epidemi SARS tahun 2003 dan MERS tahun 2012 yang terjadi di wilayah China dan wilayah Asia lainnya. Salah satu kebijakan yang diambil untuk memitigasi dampak dari epidemi SARS dan MERS adalah dengan menurunkan tarif pajak untuk meningkatkan pengeluaran, walaupun terjadi penurunan penerimaan pajak dalam jangka pendek (Youkyung, 2015). Oleh karena itu, topik terkait kebijakan pajak menarik dan penting untuk dilakukan penelitian karena kebijakan pajak yang diambil ketika pandemi akan berdampak pada perekonomian negara. Penelitian saat ini merumuskan bagaimana respon negara-negara dalam data statistik OECD terhadap kebijakan pajak pada saat pandemi COVID-19. Tujuan penelitian ini adalah untuk memetakan respon negaranegara yang terdapat dalam data statistik OECD terkait dengan kebijakan pajak pada masa pandemi COVID-19. Penelitian ini diharapkan dapat bermanfaat dalam menambah literatur terkait kebijakan pajak yang diterapkan pada saat terjadi pandemi.

\section{KAJIAN PUSTAKA \\ Definisi, Filosofi, dan Fungsi Pajak}

OECD (1996) mendefinisikan pajak sebagai pembayaran wajib kepada pemerintah dan manfaat yang diterima oleh masyarakat bersifat kontraprestasi. Putri (2013) menjelaskan bahwa kontraprestasi adalah manfaat yang diterima dari pembayaran pajak tidak sebanding dengan pajak yang dibayarkan oleh wajib pajak karena tidak ditujukan secara langsung, melainkan untuk membiayai pengeluaran negara. Dziemianowicz (2019) menjelaskan dalam penelitiannya bahwa pajak merupakan harga yang harus dibayar untuk hidup dalam masyarakat. Hal ini didukung dengan pernyataan bahwa pajak merupakan aspek fundamental dalam kehidupan modern karena pendapatan pajak dapat digunakan oleh pemerintah untuk mendukung kesejahteraan ekonomi dan sosial (Young et al., 2016). Setiap negara memiliki beberapa jenis pajak, antara lain adalah corporate income tax (CIT), personal income tax (PIT), value-added tax (VAT), dan property tax (OECD, 2020e).

Pajak memiliki peranan penting dalam mendukung dan memelihara jalannya perekonomian suatu negara (Nkundabanyanga et al., 2017). Anggaran yang digunakan oleh pemerintah salah satunya berasal dari pendapatan pajak, hal ini membuktikan bahwa pajak memiliki fungsi sebagai budgeter yaitu sumber pendapatan negara (Rohendi, 2014). Pendapatan yang berasal dari pajak dapat digunakan untuk membiayai kebutuhan negara, contohnya untuk mendukung kebutuhan sistem kesehatan ketika terjadi pandemi COVID-19. Selain itu, pajak digunakan oleh pemerintah sebagai alat untuk mengatur perekonomian negara sehingga pajak juga berfungsi sebagai regulerend (Rohendi, 2014). Pajak dapat berfungsi untuk mengelola ekonomi, dan pasar keuangan, serta untuk mendidik, melindungi, dan merawat warganya melalui kebijakan perpajakan (Yew et al., 2014). Pendapatan pajak relatif dapat diprediksi, sehingga pemerintah dapat melakukan perencanaan melalui kebijakan pajaknya (Owens \& Parry, 2009). 


\section{Kebijakan Pajak pada Masa Pandemi COVID-19}

Pandemi COVID-19 yang menyebabkan efek merugikan pada sistem kesehatan dunia memiliki pengaruh dalam segi sosial ekonomi dunia. Nicola et al. (2020) menjelaskan bahwa adanya pembatasan sosial, pembatasan perjalanan domestik maupun internasional, serta pemberlakuan karantina memicu kekhawatiran akan terjadinya krisis ekonomi dan resesi akibat terhambatnya kegiatan ekonomi. Negaranegara ASEAN menjadi contoh negara yang perekonomiannya terdampak akibat penyebaran COVID19, seperti penurunan pendapatan dari sektor pariwisata yang terjadi di Thailand dan Singapura yang masing-masing sebesar 3,7\% dan 2,5\% (ASEAN, 2020). Ozili (2020) menjelaskan bahwa efek pandemi COVID-19 juga menyebabkan Nairobi Stock Exchange menangguhkan perdagangan ekuitasnya di Maroko akibat penurunan yang terjadi melebihi 5\%. Nicola et al. (2020) menjelaskan meskipun sektor pariwisata, finansial, dan manufaktur mengalami penurunan, namun sektor industri farmasi, teknologi informasi, media, research and development justru mengalami peningkatan pendapatan.

Berdasarkan kondisi ekonomi yang terjadi, adaptasi terkait kebijakan pemerintah menjadi kunci untuk mendorong keseimbangan perekonomian, salah satunya melalui kebijakan pajak. Pemerintah berupaya mengambil langkah kebijakan pajak yang dapat memaksimalkan penerimaan pajak dari sektor yang tidak terdampak dan memberi keringanan melalui penangguhan pajak bagi sektor yang terdampak pandemi COVID-19 (International Monetary Fund, 2020). OECD (2020a) merekomendasikan kepada pemerintah untuk memfokuskan pembuatan kebijakan pajak yang dapat mendukung pendapatan rumah tangga dan menjaga likuiditas bisnis dalam konteks nasional negara masing-masing. Kebijakan pajak yang dapat diterapkan antara lain dengan menerapkan pembebasan maupun penangguhan pembayaran pajak untuk pajak properti, CIT, PIT, VAT, atau pajak konsumsi, serta memberikan waktu tambahan bagi wajib pajak untuk mengajukan pengembalian pajak (OECD, 2020e).

\section{Pajak dalam Hukum Negara}

Ginting et al. (2018) menjelaskan bahwa hukum merupakan faktor yang mendukung stabilitas ekonomi suatu negara karena memiliki peran dalam mengatur permasalahan ekonomi. Tanpa adanya hukum yang memadai permasalahan ekonomi menjadi sulit untuk ditangani dan dapat memakan waktu serta biaya yang lebih mahal (Arner, 2007). Sama halnya dengan peran hukum, pajak juga merupakan cara efektif untuk mengatur kehidupan masyarakat (Avi-Yonah, 2011). Pajak hanya dapat dipungut jika diberlakukan secara sah oleh undang-undang, diterapkan secara tidak memihak, dan harus digunakan untuk tujuan publik (Vanistendael, 1996). Sifat regulerend dari pajak tersebut ditunjukan melalui kebijakan pajak yang dikeluarkan oleh pemerintah. Kebijakan pajak merefleksikan keputusan pemerintah dalam mempertimbangkan kebijakan ekonomi dan sosial karena memengaruhi kerangka keuangan dalam aktivitas bisnis dan masalah lingkungan (European Commission, 2015).

\section{Pajak dalam Perekonomian Negara}

Pajak dalam perekonomian memiliki peran lebih dari sekadar pendapatan bagi negara, melainkan pajak memiliki peran dalam membangun perekonomian negara (Owens \& Parry, 2009). Tanzi \& Zee (2013) menjelaskan bahwa pajak merupakan salah satu cara untuk meningkatkan penerimaan negara yang dapat digunakan untuk membiayai kebutuhan akan barang dan jasa. Joseph et al. (2019) menjelaskan dalam penelitiannya bahwa pajak berperan untuk meningkatkan pendapatan untuk membiayai pengeluaran pemerintah dan mengatur kebijakan ekonomi dan sosial. Pajak merupakan alat bagi pemerintah untuk menjalankan kebijakan fiskalnya yaitu dengan menerapkan kebijakan pajak (OECD, 2014). Kebijakan pajak dapat berperan dalam meningkatkan arus kas bisnis, meningkatkan arus kas rumah tangga, serta mendukung konsumsi, investasi, sistem kesehatan, dan tenaga kerja (OECD, 2020e).

\section{Kebijakan Pajak pada Masa Sulit}

Adanya krisis kesehatan memiliki dampak pada perekonomian negara, kebijakan pajak menjadi salah satu upaya yang dapat digunakan oleh pemerintah untuk mengatasi krisis seperti yang pernah terjadi ketika epidemi SARS dan MERS yang terjadi pada tahun 2002 dan 2012. Epidemi SARS mengakibatkan negara di wilayah Asia kehilangan pendapatan sekitar US\$12-18 juta akibat adanya penurunan pada sektor pariwisata dan penjualan ritel (Qiu et al., 2018). China sebagai negara yang terdampak epidemi SARS terburuk memutuskan untuk menerapkan sistem pembebasan pajak dalam upaya untuk mendukung industri yang terdampak SARS (Lee \& Warner, 2006). Pemerintah Singapura juga menerapkan kebijakan pemotongan pajak properti untuk industri perhotelan karena adanya 
penurunan pendapatan pada sektor pariwisata akibat dari epidemi SARS (Ministry of Finance and Ministry of Trade \& Industry, 2003). H. Joo et al. (2019) menyebutkan dalam penelitiannya bahwa epidemi MERS yang terjadi di Korea Selatan pada tahun 2015 menyebabkan penurunan pendapatan dari sektor pariwisata sebesar US\$2,6 miliar dan melambatnya konsumsi serta ekspor. Kondisi tersebut membuat pemerintah Korea Selatan memutuskan untuk menerapkan kebijakan pemotongan pajak yang diharapkan dapat meningkatkan pengeluaran (Youkyung, 2015).

\section{METODE PENELITIAN}

Penelitian ini menggunakan metode penelitian deskriptif kualitatif yang menjelaskan tentang kondisi objek maupun subjek yang diteliti dan berfokus pada suatu kasus (Sugiyono, 2015). Penelitian ini dilakukan dengan tujuan untuk memetakan respon negara-negara yang terdapat dalam data statistik OECD terkait dengan kebijakan pajak pada masa pandemi COVID-19, sehingga subjek penelitian ini berupa negara-negara dalam data statistik OECD, sedangkan objek penelitian berupa kebijakan pajak yang diterapkan pada masa pandemi COVID-19. Penelitian ini dilakukan dengan dokumentasi melalui data statistik yang diperoleh melalui web resmi OECD (oecd.org) berupa dan studi literatur yang mengkaji tentang kebijakan pajak yang diterapkan oleh setiap negara dalam menghadapi masa pandemi COVID-19. Kebijakan pajak yang diterapkan dianalisis dengan mempertimbangkan jenis pajak, kebijakan pajak yang diterapkan, dan fungsinya dalam kaitannya terhadap respon yang kemudian diambil oleh pemerintah pada masa pandemi COVID-19. Identifikasi terkait jenis pajak dan fungsinya kemudian akan digunakan untuk memetakan respon setiap negara dalam menghadapi pandemi COVID19 melalui kebijakan pajak yang diterapkan.

Dalam penelitian ini, data yang dikumpulkan berupa data sekunder atau data yang diperoleh dari pihak eksternal. Data diperoleh melalui Dataset: Tax policy measures (updated 29 June 2020) yang diterbitkan oleh OECD (Organisation for Economic Co-operation and Development) dan situs resmi pemerintah. Populasi dari penelitian ini adalah negara-negara di seluruh dunia dengan sampel sebanyak 121 negara yang masuk dalam data statistik OECD dan kemudian teknik sampling data yang dilakukan menggunakan teknik purposive sampling.

Proses analisis data dalam penelitian ini diawali dengan mengumpulkan data melalui situs resmi OECD yaitu Dataset: Tax policy measures (updated 29 June 2020) dan situs resmi pemerintah. Kemudian dilakukan reduksi data berdasarkan data yang telah dikumpulkan dengan memilah setiap data yang memiliki kesamaan yang kemudian dikelompokkan atau disebut sebagai coding untuk selanjutnya dilakukan proses interpretasi. Berdasarkan reduksi data akan diperoleh kebijakan pajak yang diterapkan selama pandemi COVID-19 dan hasilnya akan digunakan sebagai kriteria dalam memetakan setiap negara yang menerapkan kebijakan tersebut. Dalam penelitian kualitatif, interpretasi yang telah dibuat selanjutnya akan dianalisis sehingga hasil pengolahan data dapat disajikan dalam bentuk naratif. Interpretasi dilakukan dengan menjelaskan pengertian dan tujuan dari kebijakan yang diterapkan, kemudian menjelaskan berapa banyak negara yang menerapkan kebijakan tersebut serta contoh dari penerapan kebijakan. Langkah terakhir, peneliti akan menarik kesimpulan berdasarkan data yang telah disajikan untuk kemudian menjawab rumusan masalah dalam penelitian ini. Kesimpulan diambil berdasarkan hasil dari kebijakan pajak yang diterapkan dan jenis pajak yang menjadi fokus penerapan kebijakan.

\section{HASIL DAN PEMBAHASAN}

Pandemi COVID-19 menyebabkan berbagai negara membatasi akses sosial masyarakat untuk mencegah penyebaran virus yang mengakibatkan penurunan penerimaan negara karena kegiatan perekonomian tidak dapat berjalan dengan maksimal salah satunya penerimaan pajak (Collier et al., 2020). Kebijakan pajak dapat digunakan oleh pemerintah untuk mengatur konsumsi masyarakat, mendorong penanaman investasi, penawaran tenaga kerja, serta pemulihan ekonomi terutama dalam kondisi pandemi COVID-19 (State Taxation Administration of The People's Republic of China, 2020). Kebijakan pajak yang diidentifikasi meliputi penangguhan pembayaran pajak, penangguhan pelaporan pajak, mempercepat pengembalian pajak, keringanan pajak, pembayaran hutang pajak yang lebih fleksibel, dan meningkatkan ketentuan kompensasi kerugian. Identifikasi kebijakan pajak difokuskan pada jenis pajak yang sebagian besar digunakan oleh setiap negara seperti CIT (corporate income tax), PIT (personal income tax), VAT (value added tax), pajak properti (property tax), dan pajak konsumsi (consumption tax). Dalam bab ini akan membahas mengenai bagaimana respon dari 121 negara yang terdapat dalam Dataset: Tax Policy Measure dalam menghadapi krisis akibat pandemi COVID-19 
dalam kaitannya terhadap kebijakan pajak. Berikut merupakan tabel terkait jumlah negara yang diidentifikasi, besarnya pendapatan pajak terhadap PDB, dan jumlah kasus COVID-19 per 31 Desember 2020 .

\begin{tabular}{lc}
\multicolumn{1}{c}{$\begin{array}{c}\text { Tabel 1 } \\
\text { Sampel }\end{array}$} \\
\hline \multicolumn{1}{c}{ Jumlah Negara Berdasarkan Area } \\
\hline Asia & 26 \\
Afrika & 17 \\
Amerika & 22 \\
Australia & 3 \\
Eropa & 53 \\
\hline Total & 121 \\
\hline & Besarnya Pendapatan Pajak terhadap PDB (\%) \\
\hline Rata-rata & 24,8 \\
Min & 0,1 \\
Max & 45,9 \\
Median & 24 \\
Jumlah negara dengan pendapatan pajak di atas median & 60 \\
Jumlah negara dengan pendapatan pajak di bawah median & 61 \\
\hline \multicolumn{2}{r}{ Jumlah Kasus COVID per 31 Desember 2020 (kasus) } \\
\hline Min & 665.347 \\
Max & 0 \\
Median & 20.258 .725 \\
Jumlah negara dengan total kasus COVID di atas median & 125.086 \\
Jumlah negara dengan total kasus COVID di bawah median & 61 \\
\hline
\end{tabular}

Sumber: Data diolah, 2020

Berdasarkan Tabel 1, sampel yang paling banyak dipakai dalam penelitian ini berasal dari negaranegara di benua Eropa dan Asia daripada negara-negara dari benua Afrika, Amerika, dan Australia. Pajak sebagai sumber pendapatan negara rata-rata menyumbang sebesar $24,8 \%$ terhadap PDB (produk domestik bruto) pada tahun 2018. Perancis tercatat sebagai negara yang memiliki pendapatan pajak tertinggi di tahun 2018 yaitu sebesar 45,9\% terhadap PDB sedangkan porsi pendapatan pajak terendah terhadap PDB tercatat sebesar 0,1\% yaitu di Uni Emirat Arab (OECD, 2019). Per 31 Desember 2020, WHO (2021) mencatat rata-rata penyebaran kasus COVID-19 sebanyak 665.347 kasus. Kasus tertinggi terjadi di Amerika Serikat yaitu sebanyak 20.258.725 kasus dan Kepulauan Cook tercatat memiliki kasus terendah dimana tidak terjadi penyebaran kasus COVID-19 yang tercatat hingga 31 Desember 2020.

\section{Penangguhan Pembayaran Pajak}

Penangguhan pembayaran pajak merupakan kebijakan dimana pemerintah memberikan fasilitas bagi wajib pajak untuk menunda batas waktu pembayaran pajak yang biasanya dibayarkan dalam jangka waktu tertentu (Capano et al., 2020). Pajak dapat dibayarkan di luar tenggat waktu normal yaitu dengan memperpanjang batas pembayaran pajak selama beberapa bulan berdasarkan ketentuan masing-masing negara. Penerapan kebijakan ini dapat ditargetkan berdasarkan sektor yang terdampak atau berdasarkan besarnya pendapatan yang diterima oleh wajib pajak. Tujuan diterapkannya kebijakan ini antara lain untuk meringankan beban wajib pajak dalam memenuhi kewajiban membayar pajak karena adanya penurunan aktivitas operasional yang juga mengancam kemampuan likuiditas mereka (OECD, 2020e). Selain itu, menurut World Bank (2020) penangguhan pembayaran pajak menjadi langkah untuk membatasi kontak langsung antara fiskus dengan wajib pajak yang memiliki kendala maupun tidak memiliki akses pembayaran pajak secara online maupun melalui kasir dan teller bank.

Tabel 2

Jumlah Negara yang Menerapkan Kebijakan Penangguhan Pembayaran Pajak

\begin{tabular}{lr}
\hline CIT (corporate income tax) & 63 \\
PIT (personal income tax) & 47 \\
VAT (value added tax) & 39 \\
Pajak konsumsi (consumption tax) & 13 \\
Pajak properti (property tax) & 20 \\
\hline
\end{tabular}

Sumber: Data diolah, 2020 
Penangguhan pembayaran pajak diterapkan pada seluruh jenis pajak yang ada yaitu CIT, PIT, VAT, pajak konsumsi, dan pajak properti, namun pada umumnya penangguhan pembayaran pajak lebih banyak dilakukan pada CIT, PIT, dan VAT. Batas waktu dan sektor yang mendapat fasilitas penangguhan pembayaran pajak setiap negara berbeda-beda tergantung dengan kondisi yang dihadapi oleh setiap negara. Contohnya pemerintah Australia menunda pembayaran pajak hingga 4 bulan sedangkan Belgia menunda pembayaran pajaknya hanya 2 bulan (The Australian Government the Treasury, 2020; OECD, 2020a). Sektor pariwisata menjadi salah satu sektor yang terdampak pandemi sehingga beberapa negara seperti Guinea, Laos, dan Malta memfokuskan kebijakan ini untuk pajak penghasilan di sektor perhotelan, penerbangan, maupun pajak properti seperti yang diterapkan oleh pemerintah Georgia (OECD, 2020a).

\section{Penangguhan Pelaporan Pajak}

Penangguhan pelaporan pajak merupakan kebijakan dimana pemerintah memberikan fasilitas bagi wajib pajak berupa memperpanjang batas waktu pelaporan pajak (Megersa, 2020). Pajak dapat dilaporkan pada tanggal tertentu di luar periode pelaporan normal dengan memperpanjang batas pelaporan selama beberapa bulan, contohnya penundaan pelaporan pajak selama 3 bulan untuk CIT di Peru dan pajak konsumsi karbon di Afrika Selatan (African Tax Administration Forum, 2020). Penerapan kebijakan ini dapat ditargetkan berdasarkan sektor yang terdampak atau berdasarkan besarnya pendapatan yang diterima oleh wajib pajak. Tenggat waktu tambahan dalam pelaporan pajak dapat dimanfaatkan bagi pemerintah untuk mengumpulkan informasi terkait pengembalian pajak yang dibutuhkan (OECD, 2020d).

Tabel 3

Jumlah Negara yang Menerapkan Kebijakan Penangguhan Pelaporan Pajak

\begin{tabular}{lr}
\hline CIT (corporate income tax) & 18 \\
PIT (personal income tax) & 19 \\
VAT (value added tax) & 10 \\
Pajak konsumsi (consumption tax) & 4 \\
Pajak properti (property tax) & 1 \\
\hline
\end{tabular}

Sumber: Data diolah, 2020

Penangguhan pelaporan pajak diterapkan pada seluruh jenis pajak yang ada yaitu CIT, PIT, VAT, pajak konsumsi, dan pajak properti, namun pada umumnya penangguhan pelaporan pajak lebih banyak dilakukan pada CIT dan PIT. Penangguhan pelaporan pajak yang diterapkan antara lain seperti Albania dan Bulgaria yang memperpanjang batas pelaporan PIT dan CIT dari 31 Maret 2020 menjadi 31 Juli 2020. Penangguhan tidak hanya berlaku untuk penyampaian SPT saja namun juga berlaku untuk pengajuan pengembalian pajak. Beberapa negara seperti Finlandia, Hongaria, India, dan Jepang memperpanjang batas pengajuan pengembalian pajak untuk VAT untuk dapat dimanfaatkan bagi wajib pajak (OECD, 2020a).

\section{Mempercepat Pengembalian Pajak}

Pengembalian pajak adalah kebijakan dimana pengembalian dana atas pajak yang telah dibayarkan akan diberikan kepada wajib pajak berdasarkan ketentuan tertentu yang diterapkan oleh negara masing-masing (Baker et al., 2020). Pengembalian pajak yang dilakukan setiap negara dapat berbeda-beda, misalnya pengembalian pajak dilakukan atas kelebihan pajak yang sebelumnya dibayarkan atau pajak yang telah dibayarkan pada periode tertentu akan dikembalikan oleh pemerintah. Dana dari pengembalian pajak dapat bermanfaat bagi wajib pajak untuk mempertahankan aktivitas bisnisnya sehingga dapat terhindar dari risiko likuiditas dan mempertahankan pengeluaran masyarakat sehingga perekonomian dapat terus berjalan (World Bank, 2020). Proses pengembalian dana harus disederhanakan dan diprioritaskan bagi sektor paling terdampak dan yang mengalami kesulitan untuk mengakses pinjaman seperti UMKM (Megersa, 2020).

\section{Tabel 4}

Jumlah Negara yang Menerapkan Kebijakan Mempercepat Pengembalian Pajak

\begin{tabular}{lr}
\hline CIT (corporate income tax) & 10 \\
PIT (personal income tax) & 5 \\
VAT (value added tax) & 21 \\
Pajak konsumsi (consumption tax) & 1 \\
Pajak property (property tax) & 0 \\
\hline Sumber: Data diolah, 2020
\end{tabular}

Sumber: Data diolah, 2020 
Berdasarkan Tabel 4, pengembalian pajak tidak diberikan untuk seluruh jenis pajak, beberapa negara hanya memberikan fasilitas pengembalian pajak untuk jenis pajak CIT, PIT, VAT, dan pajak konsumsi. Contohnya pemerintah Indonesia mempersiapkan pengembalian pajak dari VAT sebesar Rp 5 miliar yang berlaku untuk periode April hingga September 2020 dan Yunani yang mempersiapkan pengembalian pajak sebesar $€ 30.000$ (OECD, 2020a). Pengembalian pajak juga ditargetkan bagi UMKM contohnya Chili yang menargetkan 500.000 UMKM menerima fasilitas ini baik melalui pengembalian CIT dan VAT bagi UMKM yang mengalami penurunan omzet minimal 30\% (Ministry of Finance, 2020).

\section{Keringanan Pajak}

Keringanan pajak merupakan kebijakan yang memungkinkan wajib pajak untuk mengurangi beban dalam membayar pajak (Qiu et al., 2018). Keringanan pajak yang diberikan dapat berupa menurunkan tarif pajak, memotong pajak yang harus dibayar, membebaskan pajak untuk sektor tertentu dan denda atas keterlambatan pembayaran pajak. Perubahan tarif pajak berupa menurunkan tarif pajak dari tarif normal, sedangkan pemotongan pajak berupa kegiatan memotong pajak yang harus dibayarkan secara normal hingga tingkat tertentu (OECD, 2020c). Penurunan tarif pajak sebagian diterapkan untuk pajak VAT terutama untuk sektor kesehatan yang mendukung penyediaan barang terkait penanggulangan COVID-19 dan barang yang banyak dikonsumsi oleh publik. Hal ini dilakukan untuk meningkatan arus kas dalam rantai pasokan dan mendorong sistem kesehatan (African Tax Administration Forum, 2020). Pembebasan denda atas keterlambatan diterapkan karena adanya pandemi yang menyebabkan kegiatan pelaporan dan pembayaran pajak tertunda (Megersa, 2020).

Tabel 5

Jumlah Negara yang Menerapkan Kebijakan Keringanan Pajak

\begin{tabular}{lc}
\hline CIT (corporate income tax) & 35 \\
PIT (personal income tax) & 31 \\
VAT (value added tax) & 22 \\
Pajak konsumsi (consumption tax) & 17 \\
Pajak properti (property tax) & 14 \\
\hline
\end{tabular}

Sumber: Data diolah, 2020

Berdasarkan Tabel 5, keringanan pajak sebagian besar diterapkan untuk jenis pajak CIT, PIT, dan VAT. Kebijakan penurunan tarif pajak untuk CIT dan PIT yang diterapkan antara lain seperti Indonesia yang menurunkan tarif CIT dari 25\% menjadi 22\% untuk tahun 2020 dan 2021, sedangkan penurunan tarif PIT diterapkan oleh pemerintah Mesir terkait pajak atas dividen dari 10\% menjadi 5\% (OECD, 2020a). Beberapa negara juga memberlakukan tarif $0 \%$ untuk VAT seperti Austria dan Argentina yang menerapkannya kebijakan tersebut terkait impor barang yang digunakan untuk mencegah penyebaran virus, serta Kolombia menerapkan tarif 0\% untuk pajak konsumsi bagi restoran (OECD, 2020a). Selain itu, pemerintah Cina membebaskan PIT atas bonus dan subsidi yang diberikan kepada staf medis yang bekerja dalam memerangi COVID-19 (OECD, 2020a). Negara-negara seperti Belgia dan Ceko membebaskan denda atas keterlambatan pembayaran pajak, sedangkan Makedonia Utara menurunkan tarif bunga atas keterlambatan pembayaran pajak menjadi 0,15\% (OECD, 2020a).

\section{Pembayaran Hutang Pajak yang Lebih Fleksibel}

Otoritas pajak memberikan fasilitas pembayaran hutang pajak yang lebih fleksibel berupa memberikan rencana pembayaran pajak yang dapat diangsur secara bulanan atau secara triwulan selama periode tertentu (African Tax Administration Forum, 2020). Pembayaran pajak yang lebih fleksibel dapat memberikan dukungan bagi arus kas bisnis dan meringankan beban wajib pajak dalam membayar kewajiban pajaknya (OECD, 2020e). Selain itu, otoritas pajak juga dapat mempertimbangkan untuk mengembangkan sistem teknologi informasi dalam sistem perpajakannya yang memungkinkan wajib pajak untuk dapat melaporkan dan membayar pajak secara online (World Bank, 2020).

\section{Tabel 6}

Jumlah Negara yang Menerapkan Kebijakan Pembayaran Hutang Pajak yang Lebih Fleksibel

\begin{tabular}{lr}
\hline CIT (corporate income tax) & 17 \\
PIT (personal income tax) & 10 \\
VAT (value added tax) & 4 \\
Pajak konsumsi (consumption tax) & 0 \\
Pajak properti (property tax) & 1
\end{tabular}

Sumber: Data diolah, 2020 
Kebijakan pembayaran pajak yang lebih fleksibel tidak diberikan untuk seluruh jenis pajak, beberapa negara hanya memberikan fasilitas pengembalian pajak untuk jenis pajak CIT, PIT, VAT, dan pajak properti. Beberapa negara memberikan fasilitas berupa pembayaran pajak dengan cara angsuran seperti pembayaran CIT dan PIT yang dapat dilakukan dalam 3 atau 6 angsuran bulanan yang diterapkan di Portugal dan Republik Dominika (OECD, 2020a). Selain itu terkait dengan sistem pelaporan pajak, dalam kondisi pandemi ini pemerintah Makedonia Utara mempersiapkan kemudahan dalam pelaporan pajak yang dapat dilakukan melalui e-faktur dengan memasukkan tanda tangan elektronik (OECD, 2020a).

\section{Meningkatkan Kompensasi Kerugian (Loss Offset Provision)}

Ketentuan kompensasi kerugian (loss offset provision) merupakan ketentuan yang memperbolehkan perusahaan untuk mengurangi kewajiban pajak dengan menghapus kerugian operasi terhadap laba masa lalu (loss carry back) atau masa depan (loss carry forward) (Baris \& Schott, 2019). Kerugian operasi menurunkan penghasilan kena pajak pada periode kompensasi yang berpengaruh terhadap penurunan beban pajak pada masing-masing periode (Kohlhase \& Pierk, 2020). Kebijakan dalam meningkatkan kompensasi kerugian diperlukan untuk membantu perusahaan yang menghadapi risiko likuiditas dan solvabilitas (OECD, 2020e). Mekanisme kompensasi kerugian dapat memberikan kepastian pada tahun mendatang bahwa kerugian selama krisis kesehatan ini dapat dibebankan pada pembayaran pajak di masa depan (World Bank, 2020).

Tabel 7

Jumlah Negara yang Menerapkan Kebijakan Meningkatkan Ketentuan Penyisihan Kerugian

\begin{tabular}{lr}
\hline CIT (corporate income tax) & 15 \\
PIT (personal income tax) & 3 \\
VAT (value added tax) & 0 \\
Pajak konsumsi (consumption tax) & 0 \\
Pajak properti (property tax) & 0 \\
\hline
\end{tabular}

Sumber: Data diolah, 2020

Kebijakan terkait kompensasi kerugian fiskal tidak diberikan bagi semua jenis pajak melainkan untuk PIT dan CIT. Negara yang memberikan fasilitas kompensasi kerugian untuk PIT antara lain Amerika Serikat, Fiji, dan Polandia. Beberapa negara menerapkan kebijakan ini dengan memperpanjang batas penerapan kompensasi kerugian seperti Cina yang meningkatkan loss-carry forward dari 5 tahun menjadi 8 tahun dan Slovakia selama lebih dari 4 tahun (OECD, 2020a). Selain itu beberapa negara memberikan batasan terkait kerugian yang dapat dikompensasikan seperti Ceko dan Islandia yang masing-masing sebesar $\$ 1,3$ juta dan $€ 132.000$, serta Jerman dari $€ 1$ juta menjadi $€ 5$ juta untuk tahun pajak 2020 dan 2021 (OECD, 2020a).

\section{KESIMPULAN}

Hasil penelitian ini menyimpulkan bahwa pada masa pandemi COVID-19, berbagai negara menerapkan kebijakan perpajakan untuk mempertahankan stabilitas perekonomian. Kebijakan pajak yang diterapkan meliputi kebijakan penangguhan pembayaran pajak, penangguhan pelaporan pajak, mempercepat pengembalian pajak, memberikan keringanan pajak, pembayaran pajak yang lebih fleksibel, dan meningkatkan kompensasi kerugian. Kebijakan pajak yang diterapkan secara umum difokuskan pada jenis pajak CIT (Corporate Income Tax), PIT (personal income tax), dan VAT (Value Added Tax), pajak konsumsi, dan pajak properti.

Penelitian sebelumnya telah meneliti terkait kebijakan pajak yang dilakukan oleh pemerintah ketika terjadi krisis ekonomi. Penelitian tersebut dilakukan oleh Pham (2020) dan Yagan (2015) yang menyatakan krisis ekonomi global yang terjadi di Vietnam dan Amerika serikat tahun 2008 membuat pemerintah setempat menerapkan kebijakan pajak dengan memotong dan menunda pembayaran CIT selama sembilan bulan dan memotong pajak dividen. Penelitian ini berkontribusi bahwa selain krisis ekonomi, pemerintah juga menerapkan kebijakan perpajakan seperti penangguhan pelaporan pajak, mempercepat pengembalian pajak, meningkatkan ketentuan kompensasi kerugian, dan pembayaran pajak yang lebih fleksibel pada masa pandemi COVID-19. Selain itu, hasil penelitian ini diharapkan bermanfaat dalam menambah literatur bagi masyarakat agar masyarakat mengetahui upaya yang dilakukan oleh pemerintah terkait kebijakan pajak selama pandemi COVID-19.

Penelitian ini menjelaskan terkait kebijakan pajak yang diterapkan pada saat pandemi COVID19 secara global, serta jenis pajak dan tujuan dari diterapkannya kebijakan tersebut. Namun, 
keterbatasan dalam penelitian ini adalah bahwa penelitian ini sebatas memetakan kebijakan pajak tanpa melihat besaran dampak dan efektivitas dari kebijakan pajak tersebut. Penelitian selanjutnya diharapkan dapat menganalisa besaran dampak COVID-19 serta efektivitas kebijakan yang diterapkan untuk tiap negara.

\section{REFERENSI}

African Tax Administration Forum. (2020). Suggested COVID-19 measures for revenue authorities. https://www.ataftax.org/ataf-publishes-measures-to-help-manage-the-impact-of-covid-19-on-tax

Arner, D. (2007). Law, financial and development. In Financial Stability, Economic Growth, and the Role of Law (pp. 13-50). Cambridge University Press. https://doi.org/10.4337/9781784718213.00013

ASEAN. (2020). Economic impact of COVID-19 outbreak on ASEAN. In ASEAN Policy Brief (Issue April). https://asean.org/storage/2020/04/ASEAN-Policy-Brief-April-2020_FINAL.pdf

Avi-Yonah, R. S. (2011). Taxation as regulation: carbon tax, health care tax, bank tax and other regulatory taxes. Accounting, Economics and Law, l(1). https://doi.org/10.2202/2152-2820.1008

Baker, A., Traub, J., Mills, P., \& Young, C. (2020). Recovery from the COVID-19 crisis: What role will tax policy play? https://www2.deloitte.com/content/dam/Deloitte/global/Documents/Tax/dttl-taxrecovery-from-covid-19-crisis-what-role-tax-policy-play-supporting-recovery-1.pdf

Baris, K., \& Schott, I. (2019). Loss-offset provisions in the corporate tax code and misallocation of capital. 105, 1-20. https://doi.org/10.1016/j.jmoneco.2019.04.011

Capano, G., Howlett, M., Jarvis, D. S. L., Ramesh, M., \& Goyal, N. (2020). Mobilizing policy (in) capacity to fight COVID-19: Understanding variations in state responses. Policy and Society, OO(00), 1-24. https://doi.org/10.1080/14494035.2020.1787628

Collier, R., Pirlot, A., \& Vella, J. (2020). Tax policy and the COVID-19 crisis (Issue June). https://www.sbs.ox.ac.uk/sites/default/files/2020-07/WP20-01.pdf

Dziemianowicz, R. (2019). Tax policy in OECD countries in 2007-2016: trends and challenges. Ekonomia i Prawo, 18(4), 425. https://doi.org/10.12775/eip.2019.028

European Commission. (2015). Taxation: promoting the internal market and economic growth. The European Union Explained. https://doi.org/10.2775/150928

Ginting, B., Sembiring, R., Siregar, M., \& Abduh, A. (2018). The role of law in economic development: To develop a special economic zone in order to build a national and regional economy. Proceedings of MICoMS 2017, 209-214. https://doi.org/10.1108/978-1-78756-793-1-00012

Harahap, M., Sinaga, B. M., Manurung, A. H., \& Maulana, T. N. A. (2018). Dampak kebijakan dan makroekonomi terhadap efektivitas penerimaan pajak di bursa efek indonesia. Jurnal Ilmiah Manajemen, 8(2), 400-419. https://doi.org/10.22441/mix.2018.v8i2.013

International Monetary Fund. (2020). Challenges in forecasting tax revenue. https://www.imf.org/ /media/Files/Publications/covid19-special-notes/en-special-series-oncovid-19-challenges-in-forecasting-tax-revenue.ashx

Joo, H., Maskery, B. A., Berro, A. D., Rotz, L. D., Lee, Y. K., \& Brown, C. M. (2019). Economic impact of the 2015 MERS outbreak on the Republic of Korea's tourism-related industries. Health Security, 17(2), 100-108. https://doi.org/10.1089/hs.2018.0115

Joo, L. E. (2020). S. Korea's Q1 tax revenue shrinks $\$ 6.9$ bn, fiscal deficit hits record high by march. https://pulsenews.co.kr/view.php?year=2020\&no=466629

Joseph, F. I., Omodero, C. O., \& Omeonu, M. O. (2019). The role of tax revenue and foreign direct investment in promoting economic progress in nigeria. Annals of Spiru Haret University. Economic Series, 19(3), 33-54. https://doi.org/10.26458/1932

Peraturan Menteri Keuangan tentang insentif pajak untuk wajib pajak terdampak pandemi coronavirus $\begin{array}{lllll}\text { disease 2019, Pub. L. No. } & \text { 44/PMK.03/2020 }\end{array}$ https://jdih.kemenkeu.go.id/fullText/2020/44 PMK.03 2020Per.pdf

$\begin{array}{llllll}\text { Kementrian Keuangan } & \text { RI. (2020). Apbn }\end{array}$ https://www.kemenkeu.go.id/media/14243/apbn-kita-januari-2020.pdf

Kohlhase, S., \& Pierk, J. (2020). Tax rule changes and the timing of asset write-offs in loss firms. Journal of Business Finance and Accounting, August 2018, 1-26. https://doi.org/10.1111/jbfa.12502

Lee, G. O. M., \& Warner, M. (2006). The impact of SARS on China's human resources: implications 
for the labour market and level of unemployment in the service sector in Beijing, Guangzhou and Shanghai. In Review (Vol. 85, Issue 6). https://doi.org/10.20955/r.85.67

Megersa, K. (2020). Tax reforms after COVID-19 and financial crises. https://opendocs.ids.ac.uk/opendocs/handle/20.500.12413/15531

Ministry of Finance and Ministry of Trade \& Industry. (2003). Government unveils \$230 million SARS relief package. Economic Impact of SARS. https://www.mof.gov.sg/newsroom/pressreleases/Government-Unveils-\%24230-Million-SARS-Relief-Package

Ministry of Finance, R. of C. (2020). Additional policies to support household and firms from the COVID-19. https://www.hacienda.cl/english/investor-relations-office/newsletter/latest

Nicola, M., Alsafi, Z., Sohrabi, C., Kerwan, A., Al-Jabir, A., Iosifidis, C., Agha, M., \& Agha, R. (2020). The socio-economic implications of the coronavirus pandemic (COVID-19): A review. International Journal of Surgery, 78, 185-193. https://doi.org/10.1016/j.ijsu.2020.04.018

Nkundabanyanga, S. K., Mvura, P., Nyamuyonjo, D., Opiso, J., \& Nakabuye, Z. (2017). Tax compliance in a developing country: understanding taxpayers' compliance decisions by their perceptions. Journal of Economic Studies, 44(6), 931-957. https://doi.org/10.1108/JES-03-20160061

OECD. (1996). Definition of taxes. In Negotiating Group on the Multilateral Agreement on Investment (Vol. 2, Issue 3). https://www.oecd.org/daf/mai/pdf/eg2/eg2963e.pdf

OECD. (2014). Fundamental principles of taxation. In Addressing the Tax Challenges of the Digital Economy (pp. 29-51). OECD Publishing. https://doi.org/10.1787/9789264218789-en

OECD. (2019). Revenue Statistics 2019: Tax Revenue Trends in the OECD. In Www.Oe.Cd/GlobalRev-Stats-Database. www.oecd.org/tax/revenue-statistics-norway.pdf

OECD. (2020a). Covid-19 tax policy and other measures. https://www.oecd.org/tax/tax-policy/taxdatabase/

OECD. (2020b). Emergency tax policy responses to the COVID-19 pandemic: limiting damage to productive potential and protecting the vulnerable. https://oecd.dambroadcast.com/pm_7379_119_119695-dj2g5d5oun.pdf

OECD. (2020c). OECD secretariat analysis of tax treaties and the impact of the COVID-19 crisis. https://read.oecd-ilibrary.org/view/?ref=127_127237-vsdagpp2t3\&title=OECD-Secretariatanalysis-of-tax-treaties-and-the-impact-of-the-COVID-19-Crisis

OECD. (2020d). Tax administration responses to COVID-19: Measures taken to support taxpayers (Issue March). https://www.oecd.org/coronavirus/policy-responses/tax-administration-responsesto-covid-19-measures-taken-to-support-taxpayers-adc84188/

OECD. (2020e). Tax and fiscal policy in response to the coronavirus crisis: strengthening confidence and resilience. http://www.oecd.org/coronavirus/policy-responses/tax-and-fiscal-policy-inresponse-to-the-coronavirus-crisis-strengthening-confidence-and-resilience-60f640a8/

Owens, J., \& Parry, R. (2009). Why tax matters for development. OECD Centre for Tax Policy and Administration.

https://oecdobserver.org/news/archivestory.php/aid/2943/Why_tax_matters_for_development.ht $\mathrm{ml}$

Ozili, P. (2020). COVID-19 in Africa: socio-economic impact, policy response and opportunities. International Journal of Sociology and Social Policy, 1-25. https://doi.org/10.1108/IJSSP-052020-0171/full/html

Pham, A. (2020). Effects of temporary corporate income tax cuts: Evidence from Vietnam. Journal of Development Economics, 146, 102476. https://doi.org/10.1016/j.jdeveco.2020.102476

Putri, P. I. (2013). Analisis faktor-faktor yang memengaruhi kebijakan pajak. Journal of Economics and Policy, 6(2), 103-2013. https://doi.org/doi: 10.15294jejak.v7i1.3596

Qiu, W., Chu, C., Mao, A., \& Wu, J. (2018). The impacts on health, society, and economy of SARS and H7N9 Outbreaks in China: A Case Comparison Study. Journal of Environmental and Public Health, 2018. https://doi.org/10.1155/2018/2710185

Rohendi, A. (2014). Fungsi budgeter dan fungsi regulasi dalam ketentuan perpajakan indonesia. II(1), $119-126$.

State Taxation Administration of The Poeple's Republic of China. (2020). China's tax measures to combat COVID-19 win int $l$ praise. http://www.chinatax.gov.cn/eng/c101269/c5147432/content.html 
Sugiyono. (2015). Metode Penelitian Kualitatif. In Metode Penelitian Pendidikan: Pendekatan Kuantitatif, Kualitatif, dan $R \& D$ (p. 458). CV ALFABETA.

Tanzi, V., \& Zee, H. (2013). Tax Policy for Developing Countries (Working Paper No. 00/35, Issue 27). http://www.imf.org/external/pubs/ft/issues/issues27/

The Australian Government the Treasury. (2020). Supporting australian workers and business. https://ministers.treasury.gov.au/ministers/josh-frydenberg-2018/media-releases/supportingaustralian-workers-and-business

Utama, M. Y. D. (2020). Makin kompetitif, pemerintah pangkas tarif pajak badan. Direktorat Jendral Pajak. https://www.pajak.go.id/id/artikel/makin-kompetitif-pemerintah-pangkas-tarif-pajakbadan

Vanistendael, F. (1996). Legal framework for taxation. In Tax Law Design and Drafting (Vol. 1). https://www.imf.org/external/pubs/nft/1998/tlaw/eng/ch2.pdf

WHO. (2021). WHO Coronavirus Disease. WHO. https://covid19.who.int/table

World Bank. (2020). COVID-19 Revenue Administration Implications: Potential Tax Administation and Customs Measures to Respond to the Crisis. In Public Finance Administration. https://doi.org/10.4135/9781452224961.n6

Yagan, D. (2015). Capital tax reform and the real economy: the effects of the 2003 dividend tax cut. American Economic Review, 105(12), 3531-3563. https://doi.org/10.1257/aer.20130098

Yew, B. K., Milanov, V. B., \& McGee, R. W. (2014). An analysis of individual tax morale for russia: before and after flat tax reform. International Business Research, 8(1). https://doi.org/10.5539/ibr.v8n1p60

Youkyung, L. (2015, October). South Korea's economy bounces back after MERS crisis. The Jakarta Post. https://www.thejakartapost.com/news/2015/10/23/south-koreas-economy-bounces-backafter-mers-crisis.html

Young, A., Lei, L., Wong, B., \& Kwok, B. (2016). Individual tax compliance in china: a review. International Journal of Law and Management, 58(5). https://doi.org/10.1108/IJLMA-12-20150063 